\begin{tabular}{|l|l|l||}
\hline \multicolumn{2}{|c|}{ PublisherInfo } \\
\hline \hline PublisherName & $:$ & BioMed Central \\
\hline \hline PublisherLocation & $:$ & London \\
\hline \hline PublisherImprintName & $:$ & BioMed Central \\
\hline \hline
\end{tabular}

\title{
Topology prediction of membrane proteins
}

\begin{tabular}{|l|l|l||}
\hline \multicolumn{2}{|c|}{ ArticleInfo } \\
\hline \hline ArticleID & $:$ & 3598 \\
\hline \hline ArticleDOI & $:$ & $10.1186 /$ gb-2000-1-1-reports224 \\
\hline \hline ArticleCitationID & $:$ & reports224 \\
\hline \hline ArticleSequenceNumber & $:$ & 89 \\
\hline \hline ArticleCategory & $:$ & Web report \\
\hline \hline ArticleFirstPage & $:$ & 1 \\
\hline \hline ArticleLastPage & $:$ & 4 \\
\hline \hline & & RegistrationDate : 1999-11-18 \\
ArticleHistory & $:$ & Received $\quad:$ 1999-11-18 \\
\hline \hline ArticleCopyright & $:$ & BioMed Central Ltd2000 \\
\hline \hline ArticleGrants & $:$ & \\
\hline \hline ArticleContext & $:$ & 130591111 \\
\hline \hline
\end{tabular}




\section{Todd Richmond}

\section{Abstract}

The TopPred 2 server predicts the orientation and location of transmembrane helices in protein sequences.

\section{Content}

The TopPred 2 server predicts the orientation and location of transmembrane helices in protein sequences. The output of the server includes a GIF graphic of the predicted topology, a summary table of the predicted transmembrane helixes, and then a series of tabular descriptions of the best predicted structures.

\section{Navigation}

A simple introductory page links to a sequence submission page and to the source code if you wish to set up the program on your own machine. There is also a stand-alone program available for Macintosh computers (although the link to this program is currently broken on the site). Once on the sequence submission page, use of the server is simple. You paste your protein sequence into the window, check whether the protein sequence is eukaryotic or prokaryotic, select the desired confidence thresholds and the window size (length of possible transmembrane helices), and press submit.

\section{Reporter's comments}

\section{Timeliness}

Last updated 5 November 1997. 


\section{Best feature}

The graphic produced by TopPred 2 is one of the nicer images produced by transmembrane domain prediction servers.

\section{Worst feature}

There is no documentation on the website. In order to understand what everything means, you have get the original journal article describing the software.

\section{Wish list}

Instead of just specifying the position of the putative transmembrane domains with numbers, it would be useful to have, in addition, the protein sequence of the predicted helix. This makes it easier for the researcher to annotate that region in the protein sequence.

\section{Related websites}

There are a number of sites that offer transmembrane domain prediction including TMHMM: predication of transmembrane helices in proteins; Tmpred: prediction of transmembrane regions and orientation; HMMTOP: predication of transmembrane helices and topology of proteins; SOSUI: Classification and secondary structure prediction of membrane proteins.

\section{Table of links}

TopPred 2

TMHMM: predication of transmembrane helices in proteins

Tmpred: prediction of transmembrane regions and orientation

HMMTOP: predication of transmembrane helices and topology of proteins

SOSUI: Classification and secondary structure prediction of membrane proteins 


\section{References}

1. TopPred 2.

This PDF file was created after publication. 